\title{
プラズマアクチュエータを用いた翼端渦抑制の試み*
}

\author{
長谷部仁美 $*^{1}$, 中吉嗣 $*^{2}$, 深潟康二 $*^{3}$
}

\section{An Attempt for Suppression of Wing-Tip Vortex Using Plasma Actuators}

\author{
Hitomi HASEBE* ${ }^{1}$, Yoshitsugu NAKA and Koji FUKAGATA \\ *1 Department of Mechanical Engineering, Keio University \\ Hiyoshi 3-14-1, Kohoku-ku, Yokohama 223-8522, Japan
}

\begin{abstract}
Influence of the flow induced by dielectric barrier discharge (DBD) plasma actuators on the wing-tip vortex is investigated numerically and experimentally. The plasma actuators are installed on the suction side of the NACA0012 airfoil and operated in blowing and suction modes. For the numerical simulation, direct numerical simulation (DNS) based on the finite-difference immersed-boundary method is used. The DNS shows that the circulation parameter, which measures the strength of wing-tip vortex, is reduced by blowing as well as suction. At the same time, however, the lift-to-drag ratio is found to decrease by the actuation. In the experiment, a wing model with plasma actuators is set inside the wind tunnel and the velocity components are measured using a PIV system. Although suppression of wing-tip vortex is not confirmed due to insufficient strength of actuation and insufficient length of messurement area, the change of streamwise mean velocity profile is found to be similar to that of DNS.
\end{abstract}

Key Words : Plasma Actuator, Flow Control, Wing-Tip Vortex, PIV Measurement, Numerical Simulation

\section{1. 緒言}

近年，流体制御デバイスとして誘電体バリア放電（DBD）プラズマアクチュエータ（以下，プラズマアクチュ エータ）が注目されている(1)-(4)．プラズマアクチュエータは 2 枚の電極とそれに挟まれた誘電体から構成される 非常にシンプルな構造を持ち, 非対称に配置された電極間に高電圧交流を印加すると電極間にプラズマが発生す る.この際, 上部電極から下部電極へと向かう体積力が生じることで流れが誘起される. 誘起される流れは電圧, 周波数，電極幅，誘電体厚さ，電極配置，材質など多くのパラメータに左右されるが，通常その流速は $10 \mathrm{~m} / \mathrm{s}$ 以 下である．単一方向の誘起流れが生じる詳細なメカニズムについてはさまざまな議論がなされているが，電極に 露出側と被覆側が存在することによる非対称な放電によるものと考えられており, 実験および数值計算両面から その放電現象についての解析が進められている ${ }^{(5)-(8)}$.

プラズマアクチュエータは（1）可動部を持たず軽量，（2）非常に薄い構造のため空力的影響が小さい， 駆動が高速で入力に対する追随性が優れているなどの利点から，現在までに多くの応用例が報告されている，応

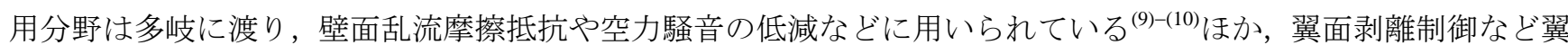
周りの流れに関する様々な研究に多く用いられている ${ }^{(11)-(13)}$.

翼周りの流れには剥離の問題以外に翼端渦と呼ばれる三次元性を持つ強力な縦渦の問題があり，その現象解明 に向けて多くの実験的研究が行われてきた ${ }^{(14)-(17)}$. 現在, 航空需要の増加に伴い航空機の離着陸回数は増加傾向 にあるが，翼端渦の発生は離着陸間隔制限の原因となっているため，その抑制は大きな課題となっている．また 近年では燃費といった環境面の観点からも翼性能を維持しつつ翼端渦を抑制することが重要となっている ${ }^{(18)}$.

翼端渦の抑制手法としてはウイングレット ${ }^{(18)}{ }^{(19)}$ に代表されるパッシブな手法が既に実用化されているが，さ

*原稿受付 2010 年 8 月 18 日

*1 学生員, 慶應義塾大学大学院理工学研究科（†223-8522 神奈川県横浜市港北区日吉 3-14-1)

*2 正員, Laboratoire de Mécanique de Lille（Bv Paul Langevin Cité Scientifique, 59655, Villeneuve d'Ascq Cédex)

*3 正員, 慶應義塾大学理工学部（干223-8522 神奈川県横浜市港北区日吉 3-14-1)

E-mail: hasebe@fukagata.mech.keio.ac.jp 


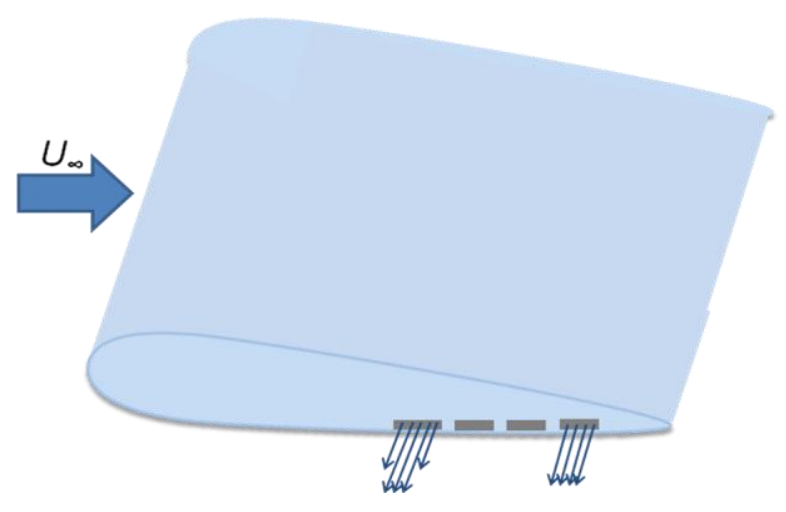

Fig. 1 Schematic of a wing with spanwise blowing slots.

らに大きな効果を求めて，吹出し・吸込みを用いたアクティブな手法が研究されている(20)-(22). 図 1 にその模式 図を示す．側面スロットからの吹出し・吸込みに関しては，定常的なものあるいは周期的に変化させるものが報 告されている. 中でも吹出しによる研究は多く行われ，吹出し方向により揚力増加の効果が大きく異なること， 吹出し量や吹出し方向の違いにより翼端渦発生位置や渦直径に違いが現れることが実験的に示されている ${ }^{(21)}$. 吹 出しに比べると吸込みを用いた研究例は少ないが，吸込みを用いた研究では翼上面・後縁（吹き上げ速度最大点） 付近での翼端渦抑制効果が報告されている(22).

スロットを用いた吹出し・吸込みデバイスの翼への実装は容易ではない。しかし，より簡単な構造のプラズマア クチュエータを用いた吹出し・吸込みでスロットと同様の効果が得られれば。アクティブ制御による翼端渦抑制技 術の実用化への大きな一歩となる。 また近年ではマイクロマシン（MEMS）技術を用いたマイクロ・プラズマアク チュエータも開発されており (23)，これを用いることにより小型飛翔体（MAV など）における翼端渦抑制も期待で きる.

そこで本研究では，プラズマアクチュエータを設置した翼の周りの流れの三次元数值シミュレーションにより プラズマアクチュエータによる誘起流れが翼端渦生成に及ぼす影響を調心゙，さらに同様のアクチュエータ配置を 施した翼模型を用いた風洞実験によってプラズマアクチュエータの効果を検証することを目的としている.

\section{2. 数值シミュレーション手法}

\section{$2 \cdot 1$ 計算条件および手法}

図 2 に示すように，計算対象は空間内に NACA0012 翼を有する系である. 流れ方向には一様流入および対流流 出条件を，流れと垂直方向とスパン方向には周期境界条件をそれぞれ課す，一様流速 $U_{\infty}$ およびコード長 $c$ で定義 されるレイノルズ数は $\operatorname{Re}=U_{\infty} c / v=3000$ ，迎え角は $10^{\circ}$ とした.

流れ場の解析には直接数值シミュレーション(DNS) を用いた. DNS コードはチャネル乱流コード(24)をもとに, 上述の境界条件に变更したものを用いた。空間離散化には二次精度エネルギー保存型有限差分法 ${ }^{(25)}$ ，時間積分に

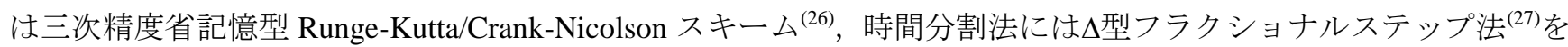
用いた．主流方向に非周期的な計算領域での圧力ポアソン方程式は鏡像法を適用した高速フーリエ変換 ${ }^{(28)}$ を用い て解いた.また, デカルト座標系格子を用い, 翼面における滑りなし境界条件の扱いには埋め込み境界法 (Immersed boundary method）(29)を用いた。

計算領域は翼のコード長 $c$ で無次元化されており, 無次元での計算領域長は流れ $(x)$ 方向, 垂直 $(y)$ 方向, スパン $(z)$ 方向にそれぞれ $12 c \times 2 c \times 6 c$, 格子数は $256 \times 96 \times 128$ ある. 格子幅は $x, z$ 方向には等間隔で $\Delta x=0.047$, $\Delta z=0.047, y$ 方向には不等間隔格子で最小格子幅は $\Delta y_{\min }=0.004$ である. $y$ 方向に関しては翼近傍における洞構 造を解像するために格子を密に配置した. また時間刻み幅 $\Delta t$ は主流速度に基づくクーラン数が $U_{\infty} \Delta t / \Delta x \leqq 0.5$ とな るように設定した。これらの条件は Taira et al. ${ }^{(30)}$ こよる平板翼周り流れの計算条件と同等に設定しており, 本計 算における時空間解像度は十分であると考えられる. 

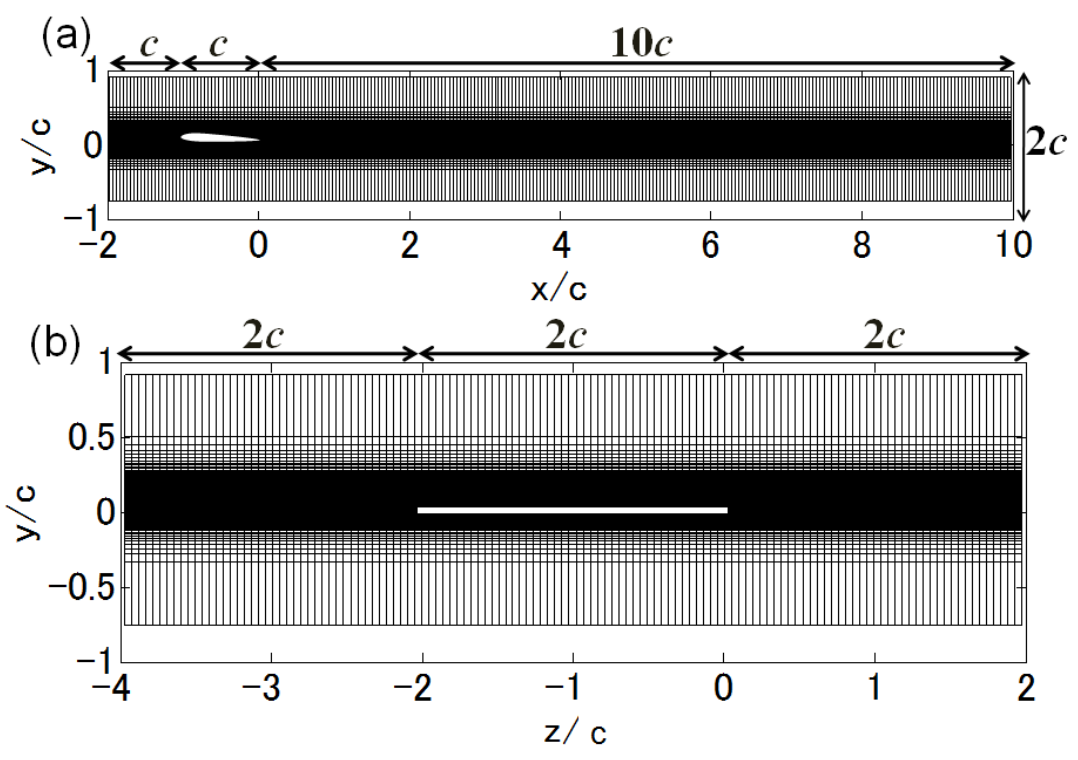

Fig. 2 Computational grid: (a) $x-y$ plane, (b) $y-z$ plane.

\section{$2 \cdot 2$ 制御手法}

プラズマアクチュエータによる体積力の影響を評価するために，プラズマアクチュエータによって誘起される 体積力 $\mathbf{f}_{\mathrm{PA}}$ を考慮した．支配方程式は，非圧縮の連続の式と，体積力を加えた Navier-Stokes 方程式である.

$$
\nabla \cdot \mathbf{u}=0
$$

$$
\frac{\partial \mathbf{u}}{\partial t}=-\nabla \cdot(\mathbf{u u})-\frac{1}{\rho} \nabla p+v \nabla^{2} \mathbf{u}+\mathbf{f}_{P A}
$$

実際の流れ場におけるプラズマアクチュエータによる体積力はマイクロ〜ミリ秒オーダーの時間分布を持つが. 本研究では簡単化のため，時間平均体積力モデルである Shyy et al. ${ }^{(31)}$ のモデルを用いた．このモデルでは，図 3 に示すように三角形の領域内でのみプラズマが発生し，電界の大きさは原点から離れるにつれ小さくなると仮定 している. 入力電圧の周期で時間平均された体積力ベクトルは

$$
\mathbf{f}_{P A}=f \alpha \rho_{c} e_{c} \Delta t \mathbf{E} \delta
$$

と表される．ここで $f$ は交流周波数， $\alpha$ は衝突係数， $\rho_{\mathrm{c}}$ は電荷密度， $e_{\mathrm{c}}$ は電気素量， $\Delta t$ は交流周期あたりの体積 力が作用する時間， E は電界ベクトル

$$
\mathbf{E}=\left(\frac{E k_{2}}{\sqrt{k_{1}^{2}+k_{2}^{2}}}, \frac{E k_{1}}{\sqrt{k_{1}^{2}+k_{2}^{2}}}\right)
$$

を表し， $\delta$ は電界強度 $E=|\mathbf{E}|$ が破壊電界 $E_{b}$ より大きい場合に 1 , それ以下では 0 の值を取る. また座標 $\left(\xi_{1}, \xi_{2}\right)$ に おける電界の大きさは

$$
E\left(\xi_{1}, \xi_{2}\right)=E_{0}-k_{1} \xi_{1}-k_{2} \xi_{2}
$$


と表される. 図 4 に示すように，プラズマアクチュエータは負圧面の各翼縁に 3 つずつ設置した．体積力の方向 としては翼面の内側に向かう Suction（図 4，青矢印）と翼面の外側に向かうBlowing（図 4，赤矢印）のケースを 考えた. 以下，それぞれのケースを Blowing および Suction と記述し，また，アクチュエータを駆動しないケース を No Control (NC) と記述する. また各パラメータは $E_{0}=2.26 \times 10^{7} \mathrm{~V} / \mathrm{m}, E_{\mathrm{b}}=3 \times 10^{2} \mathrm{~V} / \mathrm{m}, a=1 \mathrm{~mm}, b=2 \mathrm{~mm}, k_{1}$ $=\left(E_{0}-E_{\mathrm{b}}\right) / a, k_{2}=\left(E_{0}-E_{\mathrm{b}}\right) / b$ とした．その他のパラメータはプラズマアクチュエータによる誘起流速が翼端直下流 における翼端渦の周方向最大速度に相当する主流の $25 \%$ 程度となるように選定したが，実際のアクチュエータ近 傍のスパン方向流速は流れ場との相互作用によって決まる．数值シミュレーションの結果として得られた，アク チュエータ中央部におけるスパン方向速度分布を図 5 に示寸. Blowing のケース（図 5(a)）では, 内側から $2 つ$ 目のプラズマアクチュエータまでは, 体積力により主流の約 $20 \%$ の誘起流速が生み出されたが，誘起流速の方向 が巻き上がりの方向と対向するため, 翼端におけるスパン方向流速は主流の約 $10 \%$ であった. Suction のケース

（図 5(b)）では翼端に近い位置において最も流速が大きくなっており，主流の約 38\%であった.

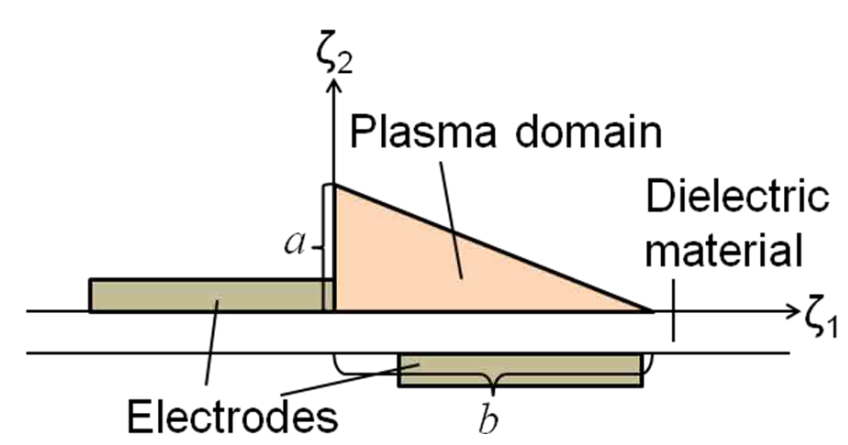

Fig. 3 Shyy et al.'s model. ${ }^{(31)}$

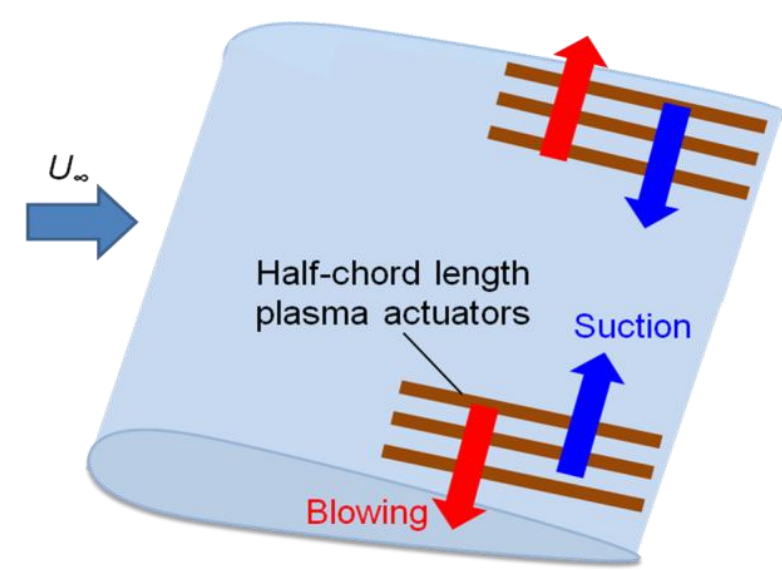

Fig. 4 PA configuration (simulation).

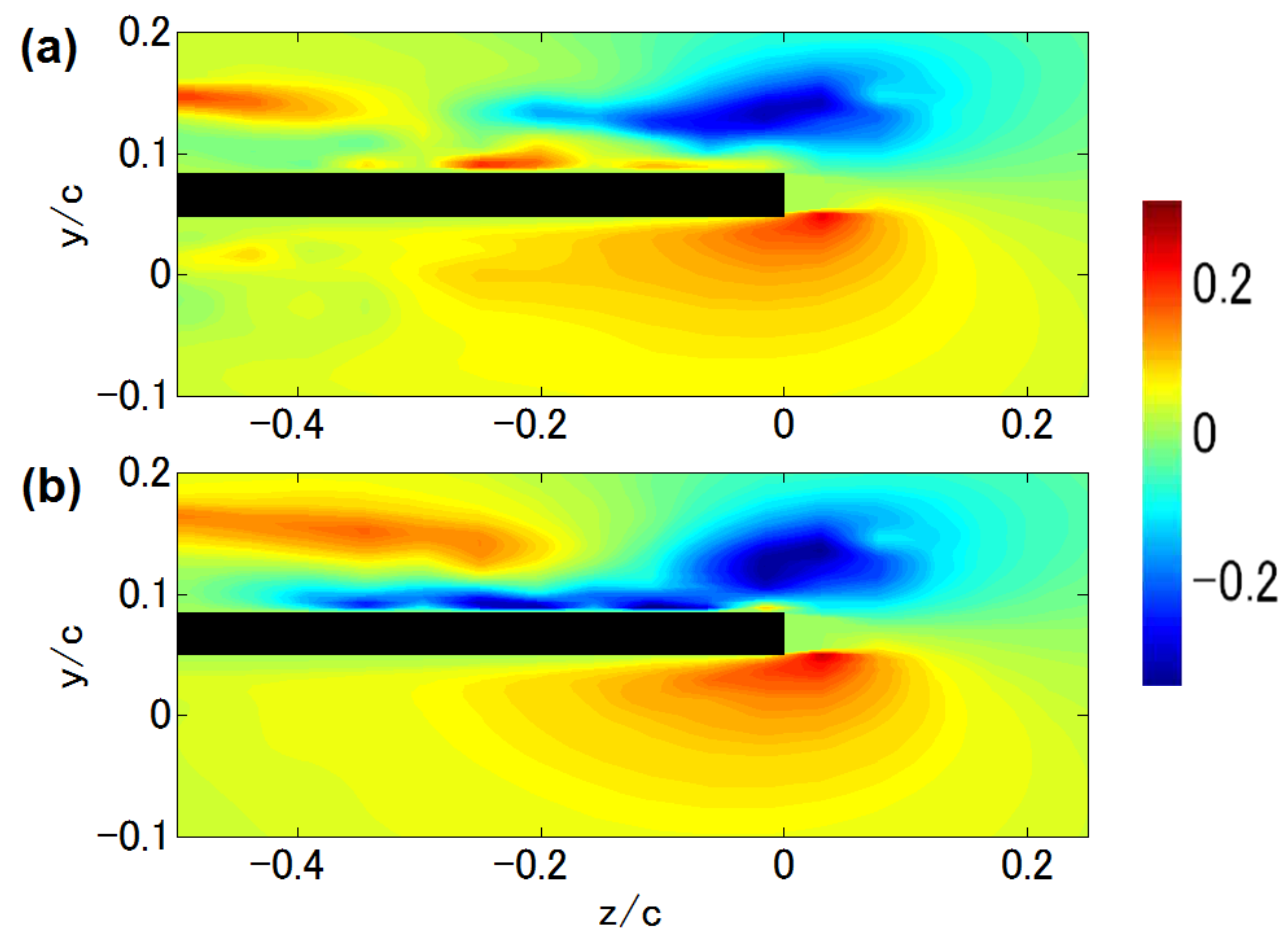

Fig. 5 Spanwise velocity $W / U_{\infty}$ at the center of plasma actuators: (a) blowing case; (b) suction case. 


\section{3. 数值シミュレーション結果および考察}

\section{$3 \cdot 1$ 揚力係数 - 抗力係数}

図 6 に統計的定常状態に至った後の時刻における揚力係数 $C_{L}$, 抗力係数 $C_{D}$, および揚抗比 $C_{L} / C_{D}$ の時間変化 を示す．揚力と抗力はそれぞれ圧力寄与分と摩擦寄与分の和から求めている. うち圧力寄与分は局所線形近似し た物体表面における圧力の表面積分で，また寄与の小さい摩擦寄与分は簡単のため階段状近似した表面積分で求 めている. Suctionのケースでは揚力係数・抗力係数ともに減少が見られ（図 5(a), (b)），その結果揚抗比が低下 している (図 5(c)) . Blowing のケースでも同様に抗力係数・揚力係数ともに減少しており, 翼性能の低下が見 られる. しかし揚力係数の減少率よりも抗力係数の減少率が大きいため, Suction のケースと比較すると揚抗比の 低下は抑えられている. また揚力および抗力に見られる周期的変動は負圧面からの渦放出に対応しているが，

Blowing, Suctionのケースともにその振幅が減少していることが分かる.

\section{$3 \cdot 2$ 流れ場の変化}

図 7 に速度勾配テンソル第二不変量 $Q$ を用いて可視化した渦構造, および $x / c=0.5$ 断面における主流方向平均 速度分布および断面内平均速度ベクトルを示す．渦構造の可視化（左図）から，Blowing のケースでは後流にお いて主流方向に軸を持つ二次元的な翼端渦の構造自体が消失しており, Suction のケースにおいては NCのケース よりも細く摇動の小さな翼端渦になっていることが確認できる. また, 翼下流 $x / c=0.5$ 断面における平均速度場 （右図）を見ると，まずNCのケースでは巻き上がりにより渦が生じている様子が確認できる. Suctionのケース では渦中心における速度欠損は大きいが，その領域は縮小している。一方 Blowing のケースにおいては渦中心に おける速度欠損や領域の大きさは NC の場合とほぼ同じであるが，渦形状の歪みが大きくなっている.

(a)

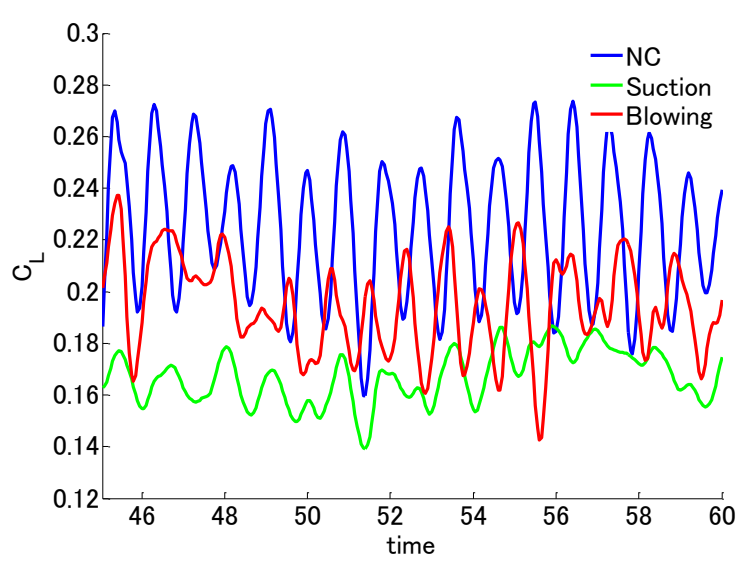

(c)

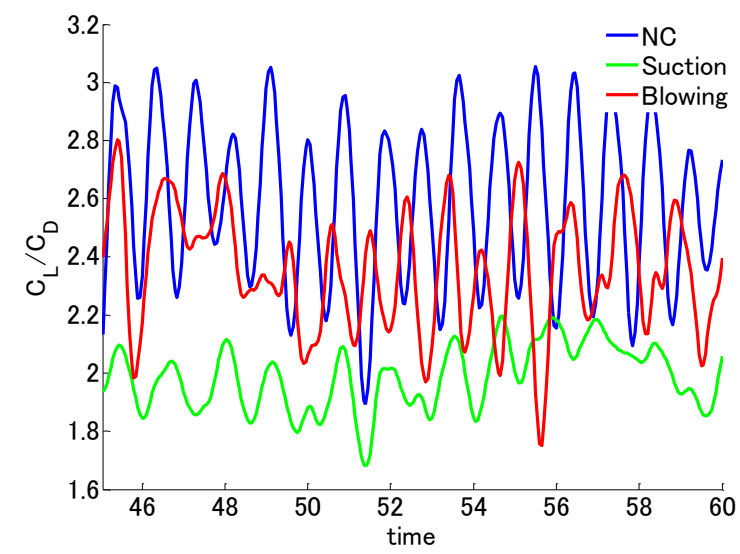

(b)

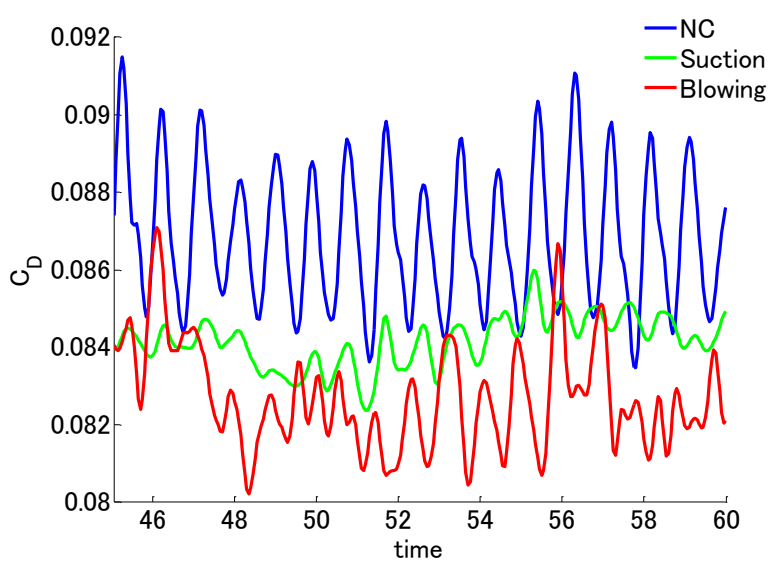

Fig. 6 Time traces: (a) lift coefficient; (b) drag coefficient; (c) lift to drag ratio. 
(a)
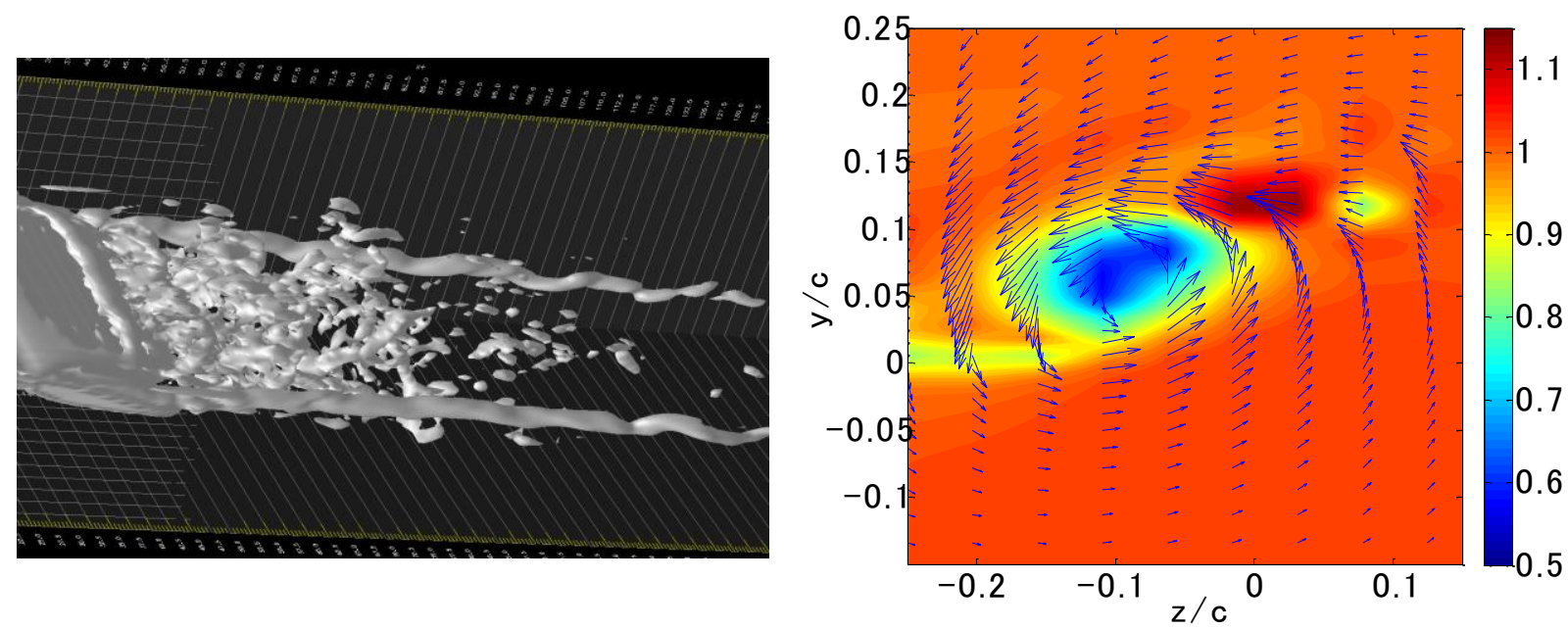

(b)
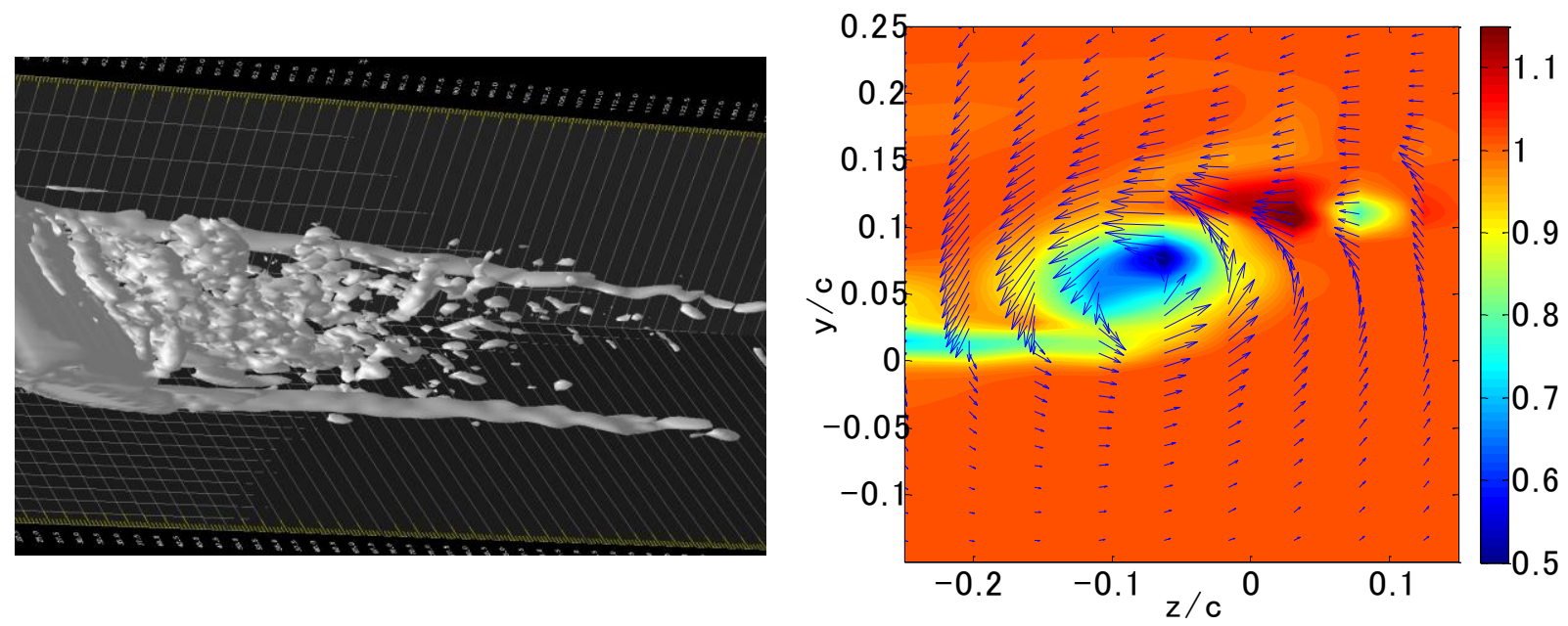

(c)
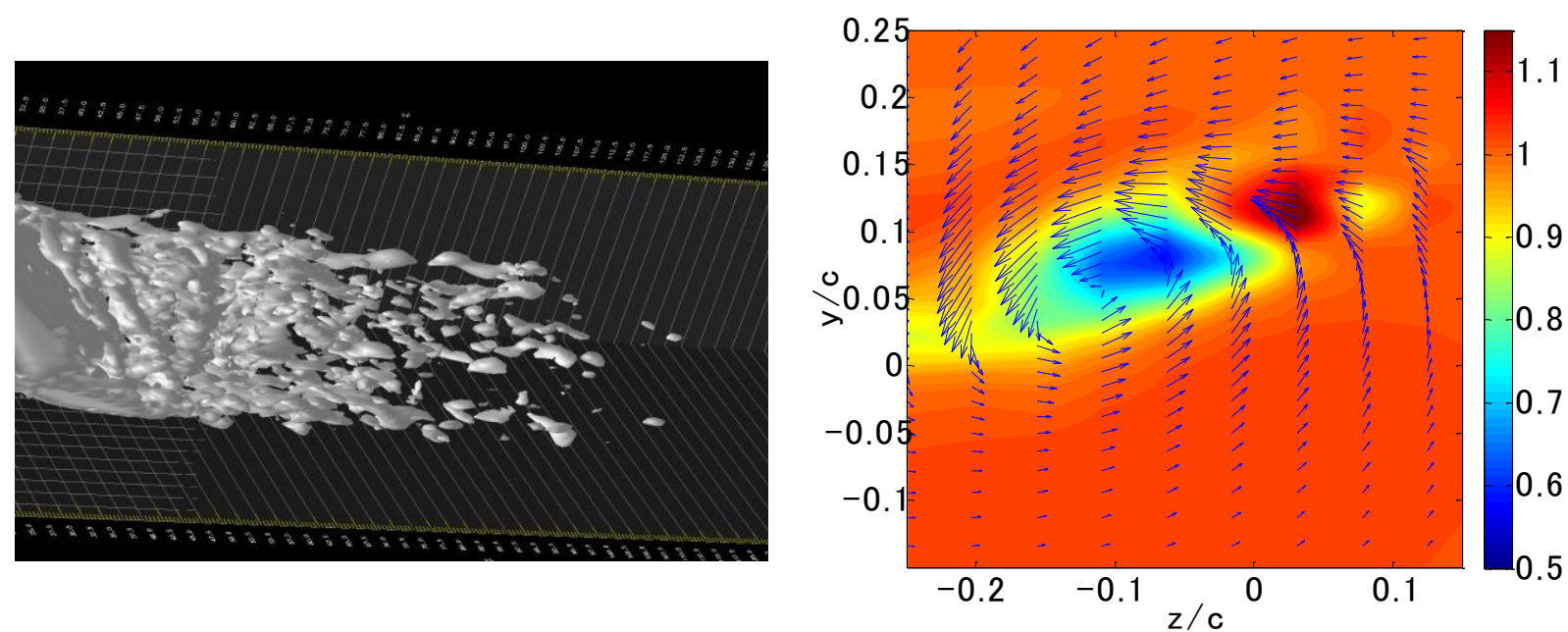

Fig. 7 Flow structures: left, instantaneous vortical structures; right, mean streamwise velocity (color) and cross-sectional velocity (vectors) at $x / c=0.5$ : (a) no control; (b) suction; (c) blowing. 
図 8 に $x / c=0.5$ における渦中心近傍での主流方向平均速度 $U$ および平均圧力 $P$ の $y$ 方向分布を示す. ここで $z$ 位置は各ケースにおける渦中心の $z$ である. 本研究では, 渦中心は速度成分 $V, W$ 共にゼロとなる点と定めた。 図8(a)から分かるように, 渦中心近傍に生じる速度欠損の大きさはNCのケースでは主流速度の約 $42 \%$ でるが, アクチュエーションを加えることで大きな変化が生じていることが確認できる. Suction のケースでは速度欠損が 主流速度の約 $50 \%$ まで増加し，その領域も縮小し，渦内部の速度勾配が大きくなっている，一方 Blowing のケー スでは速度欠損はその位置の変化を除くと NCのケースとさほど変化が見られないが，圧力に関しては大幅に回 復している(図 8(b)) 。

図 9 には $x / c=0.5$ における渦中心近傍での垂直方向平均速度 $V$ の $z$ 方向分布とスパン方向平均速度 $W$ の $y$ 方向 分布（ $y$ 位置は渦中心の $y$ 座標）を示す.アクチュエーションを加えることで $V, W$ の最大值，渦半径，および 渦中心位置に変化が生じていることが分かる．特に Blowing のケースでは周方向速度（ $V$ および $W ）$ の減少が顕 著である. 図9 の速度分布を基に描いた渦の概形を図 10 に示寸が，NCのケースでは $z$ 方向に長細い形状をして おり $,+y,-z$ 方向半径が大きくなっている. Blowing および Suctionのケースにおいても同様の傾向を示している が，Blowing のケースでは NCのケースよりも渦直径が大きくなっており，Suctionのケースでは逆に小さくなっ ている.

(a)

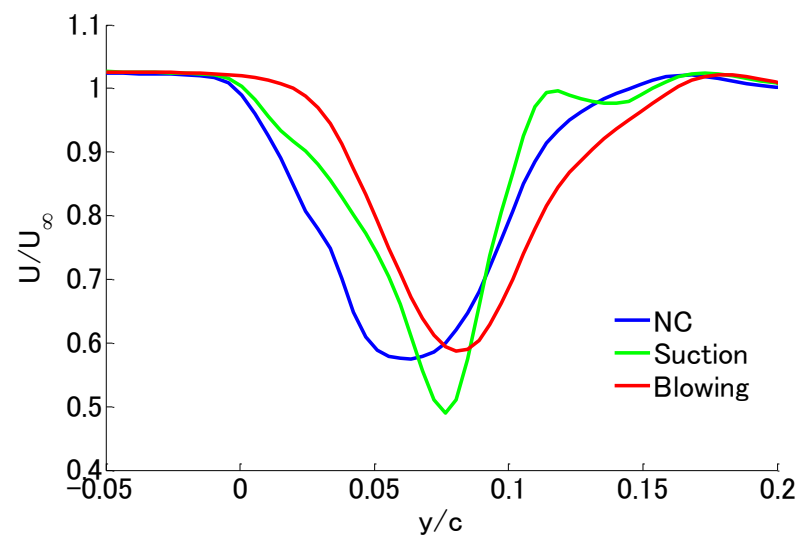

(b)

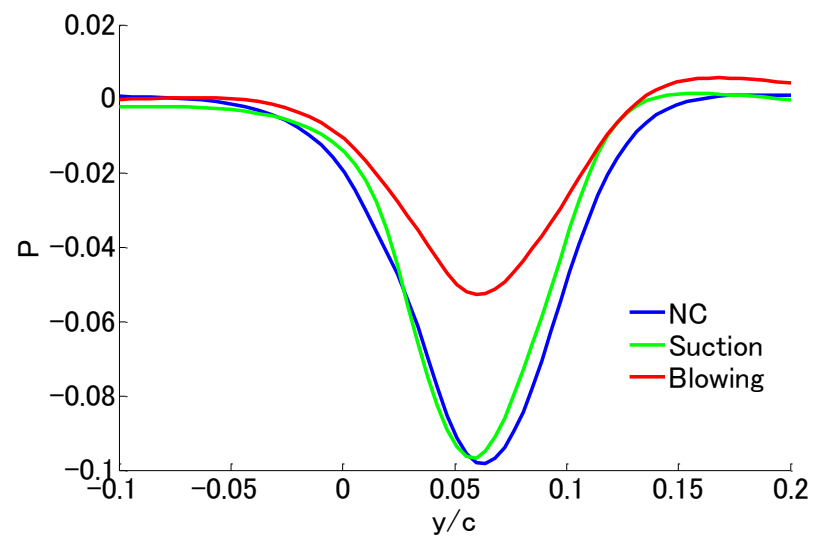

Fig. 8 Streamwise velocity and pressure at $x / c=0.5$ : (a) mean streamwise velocity $U$; (b) mean pressure $P$.

(a)

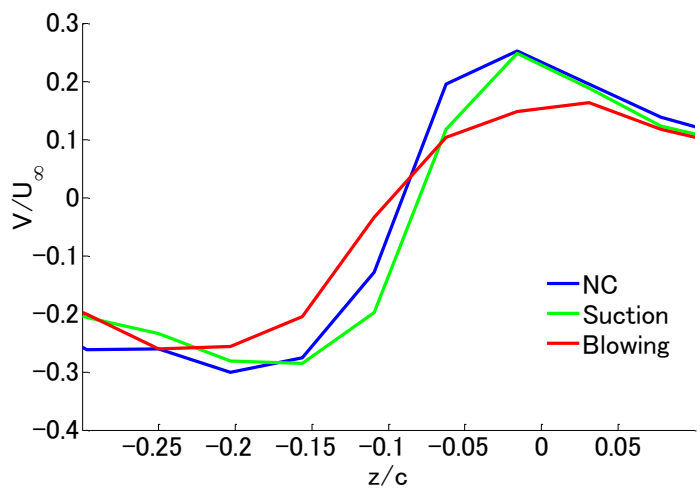

(b)

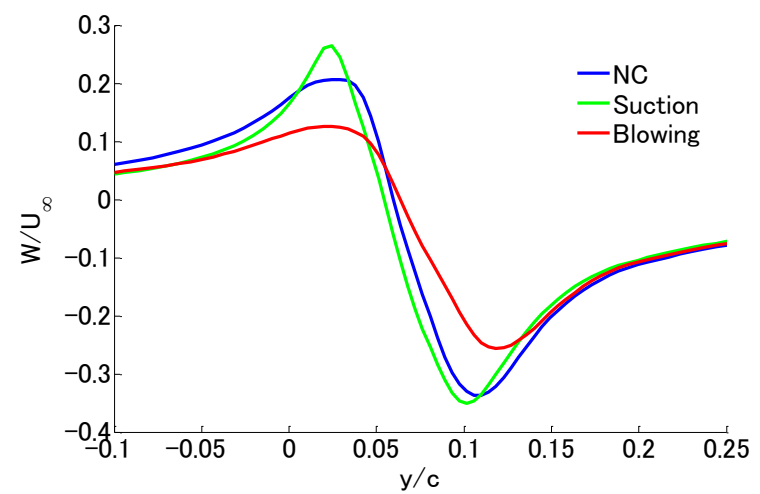

Fig. 9 Cross-sectional velocities at $x / c=0.5$ : (a) mean vertical velocity $V$ as a function of $z$; (b) mean spanwise velocity $W$ as a function of $y$. 


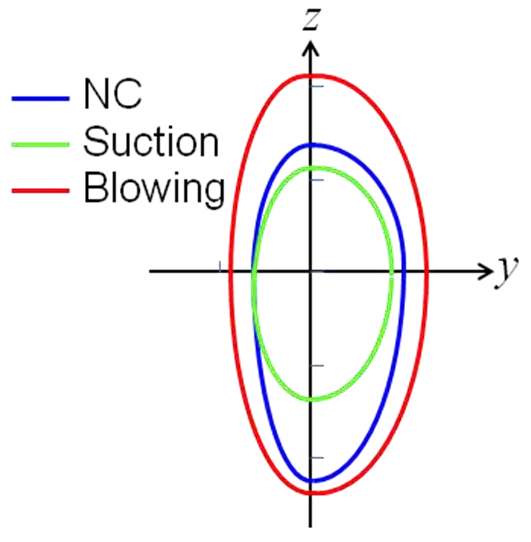

Fig. 10 Schematic of vortex shape.

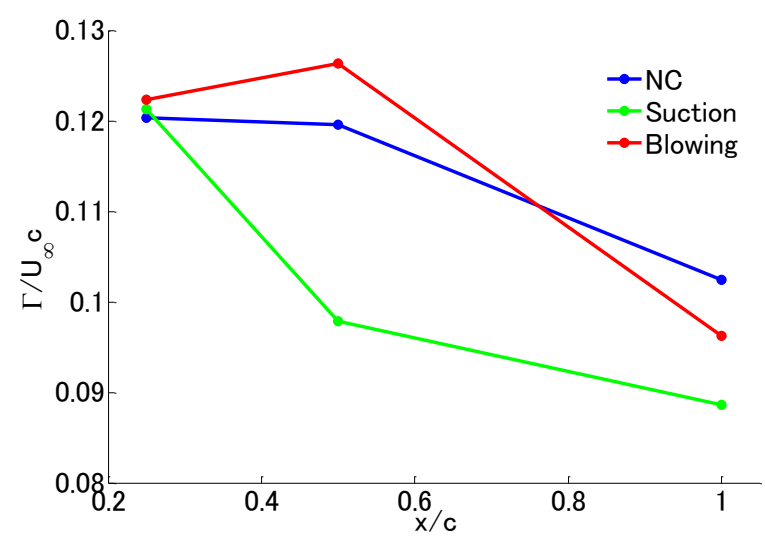

Fig. 12 Circulation parameter.

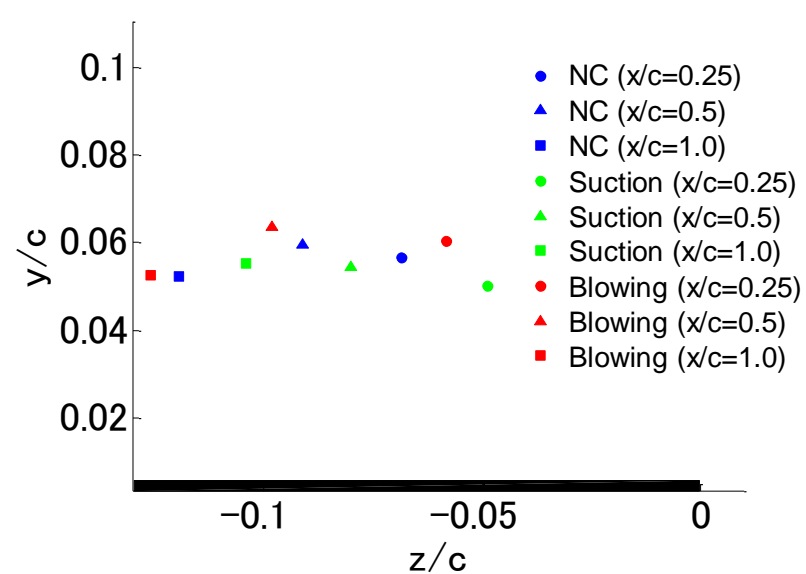

Fig. 11 Position of the vortex center.

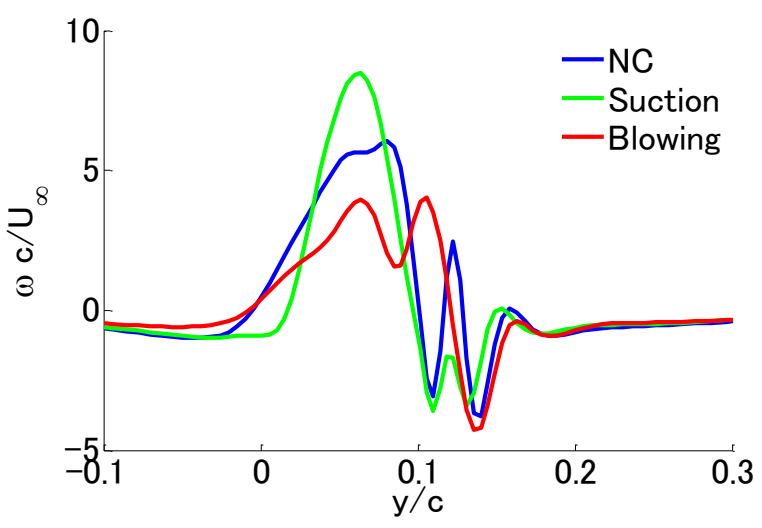

Fig. 13 Mean streamwise vorticity at $x / c=1.0$.

図 11 に $x / c=0.25,0.5$ および 1.0 断面における渦中心位置を示す. NCのケースでは過去の実験 ${ }^{(14)}$ と同様，後 流にいくにつれ $-z$ 方向へと渦中心位置が移動していくが, Blowing, Suction のケースにおいても似た挙動を示し ている。しかし SuctionのケースではNCのケースよりもより翼端に近い位置で, Blowing のケースではより翼端 から遠い位置に渦中心がある。これはプラズマアクチュエータによる誘起流れの方向によるものであると考えら れる. 即ち, Suctionのケースでは巻き上がりと同方向に流れが誘起され，負圧面側での巻き上がりが早められる 一方，Blowing のケースでは巻き上がりに抗する方向に流れが誘起され，翼端から離れた位置まで巻き上がりが 広がるためであると考えられる.

図 12 に循環パラメータ $\Gamma /\left(U_{\infty} c\right)$ による比較結果を示す.循環 $\Gamma$ 值は用いる積分領域の大きさに依存するが(15), 本研究では便宜上 $\Gamma=2 \pi R V_{\theta}$ （ここに $R$ は周方向速度 $V_{\theta}$ が最大となる位置より定義される渦半径）と定義した. Suctionのケースでは，スロットを用いた吸込みの場合 ${ }^{(22)}$ と同様，下流の $x / c=1.0$ において約 $20 \%$ の低減が見ら れた. 一方 Blowing のケースにおいては $x / c=0.5$ においてアクチュエーションによる運動量付加の直接的な影響 と思われる増加が見られたが，下流の $x / c=1.0$ では約 $10 \%$ の減少が確認できた. 従って，本数值シミュレーショ ンでは Blowing および Suctionのケースともに下流において翼端渦は弱まっていると言える.

下流領域における循環パラメータの変化は, 図 12 に示す $x / c=1$ における主流方向平均渦度分布から説明できる. Suctionのケースでは循環への寄与が小さい渦中心における渦度は増加するが, 渦中心から離れた領域における渦 度が減少している，逆に Blowing のケースでは渦度分布の広がりは若干増加するが，全体的に渦度が減少してい る.これも上述の渦中心位置の変化に対する議論と同様，巻き上がり方向と誘起流れ方向の関係で説明できる. 


\section{4. 風洞実験}

\section{4・1 実験の位置づけ}

数值シミュレーションによって得られた効果を検証すべく，プラズマアクチュエータを設置した翼模型を用い た風洞実験を行った.ただし，実験装置の制約上，パラメータは前節の数值シミュレーションとは異なる.特に， プラズマアクチュエータが誘起する流速は，数值シミュレーションでは主流速度の $25 \%$ 程度としたが，風洞実験 では主流速度の約 $10 \%$ であ.また，レイノルズ数も 2 桁高い. 同一のパラメータのもとでの定量的な比較に関 しては今後の課題とし,ここでは主にプラズマアクチュエータが流れに与える影響の定性的な比較を目的とする.

\section{$4 \cdot 2$ 実験装置}

粒子画像流速測定法（PIV）を用いて翼端付近の渦構造の可視化と速度分布計測を行った. 実験装置の模式図 を図 14 に示す. 断面 $200 \mathrm{~mm} \times 200 \mathrm{~mm}$ の開放噴出型風洞の先に長さ $580 \mathrm{~mm}$ のテストセクションを取り付け，そ の中に翼模型を設置した。今回用いた風洞の乱れ強さは風速 $10 \mathrm{~m} / \mathrm{s}$ 以上において $0.5 \%$ 上下である. 気流条件は 流速 $U_{\infty}=11 \mathrm{~m} / \mathrm{s}$ ，コード長と主流速度に基づくレイノルズ数は $\operatorname{Re}_{\mathrm{c}}=U_{\infty} c / v=1.44 \times 10^{5}$ ，迎角 10 度である. 翼に はセミスパン長 $b=100 \mathrm{~mm}$ ，コード長 $c=200 \mathrm{~mm}$ ，断面形状 NACA0012 の翼模型を用いた. 測定は $x-z$ 断面で 行い-15 mm $\leqq y \leqq 35 \mathrm{~mm}$ で $5 \mathrm{~mm}$ 間隔の全 11 断面，各断面あたり 50 回の撮影を行なった. 本実験では産業 技術総合研究所の PIV システムを用いた。光源には $25 \mathrm{~mJ} / \mathrm{pulse}$ のダブルパルス Nd-YAGレーザー（New Wave Research Co. Ltd., MiniLaser- II , 20 Hz）を使用し，1280×1024 画素の解像度を有する PIV 用クロスコリレーション カメラ（TSI, PIVCAM13-8） で短時間間隔 $100 \mu \mathrm{s} の 2$ 枚の可視化画像を取得することで， $(x, z)$ 断面内における 速度ベクトルの解析を行った. 撮影の繰返し周波数は $3.75 \mathrm{~Hz}$ であり, 可視化粒子には DOS (セバシン酸ジオクチ ル)をラスキンノズルを用いて $1 \mu \mathrm{m}$ 程度の液滴に微粒化したものを使用した.

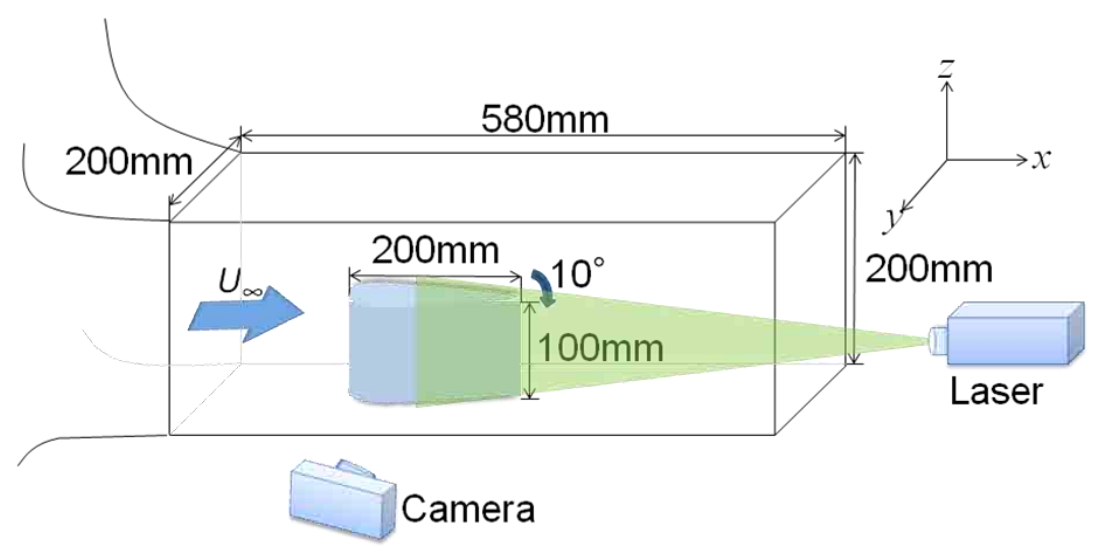

Fig. 14 Schematic of the test section.

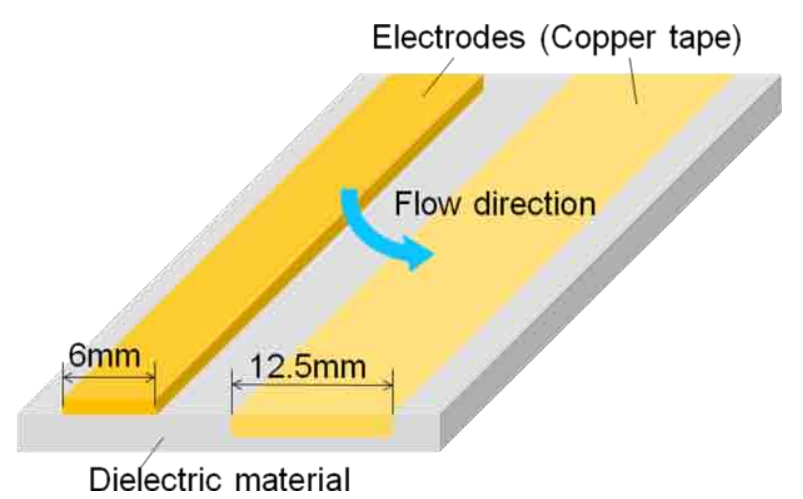

Fig. 15 Dimensions of plasma actuator used in experiment.

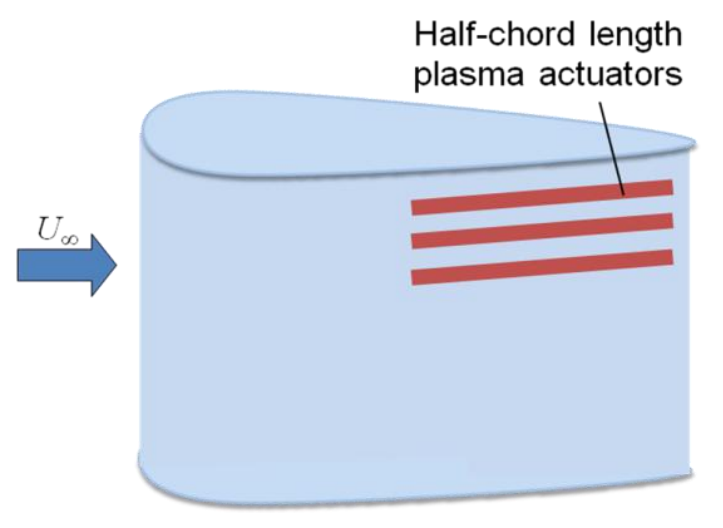

Fig. 16 PA Configuration (experiment). 
実験で用いたプラズマアクチュエータの模式図を図 15 に，その翼面への設置位置を図 16 に示す．電極には導 電性銅箔テープ (寺岡製作所, No. 8321, 厚さ $0.09 \mathrm{~mm}$ ), 誘電体にポリイミドテープ（日東電工， No. 360UL, 厚さ $0.09 \mathrm{~mm}$ ）を用いた．上部電極幅を $w_{1}=6 \mathrm{~mm}$ ，下部電極幅を $w_{2}=12.5 \mathrm{~mm}$ とした．これは Forte ${ }^{(32)}$ の結果 から最も誘起流速が大きくなるとされている值である. 前節の数值シミュレーションと同様，プラズマアクチュ エータは負圧面側にスパン方向へ流れが誘起されるように 3 個配置し，誘起方向が Suction，Blowing の 2 ケース について計測を行った，プラズマアクチュエータには，高電圧高周波電源（ケーアイテック，PSI-PG1040F）用 いて電圧の RMS 值を $4 \mathrm{kV}$, 周波数を $5 \mathrm{kHz}$ として擬似矩形波の交流電圧を印加した. 誘起流速は約 $1 \mathrm{~m} / \mathrm{s}$ である.

\section{$4 \cdot 3$ 実験結果および考察}

図 17 に渦中心位置の変化を示寸，数值シミュレーション結果（図 11）と同様，どのケースにおいても翼下流 にいくにつれ $y,-z$ 方向へと渦中心が移動していることが分かる．しかし， NC のケースからの渦中心位置の変 化に関しては, Blowing のケースでは数值シミュレーションとは逆に $-y,+z$ 方向へと移動, Suctionのケースでは 殆ど渦中心位置の変化は見られないという結果が得られた.

図 18 に渦中心を通る $x-z$ 断面におけるスパン方向平均速度 $W$ の分布を示寸. Blowing のケースでは渦生成開 始位置が翼下流側へと移動していることが確認でき，吹出しにより渦の生成が抑えられたと考えられる。しかし さらに下流では渦直径を比較すると，同様の大きさまで渦が成長していることから，Blowing による渦生成の抑 制は局所的なものであり, 一旦渦が生成した後の発達率は逆に増していると考えられる.

図 19 に $x / c=0.5$ における渦中心近傍での主流方向平均速度 $U$ の $y$ 方向分布を示寸. 数值シミュレーション結 果（図 8）と同様，Blowing のケースでは速度欠損の大きさはさほど変化せずに中心位置が+y 方向にシフトして おり, Suctionのケースでは僅かながら速度欠損の増加が確認できる.

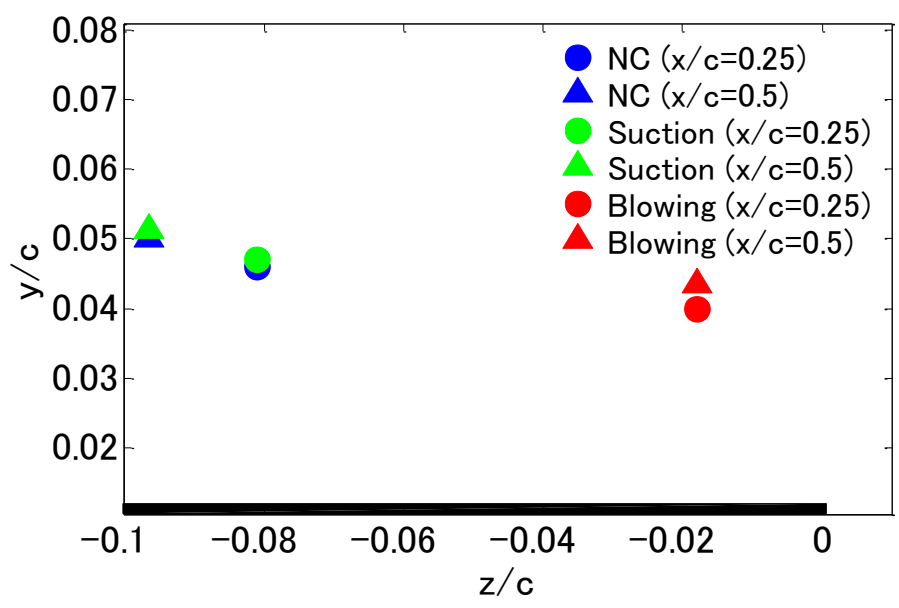

Fig. 17 Position of the vortex center (experiment).

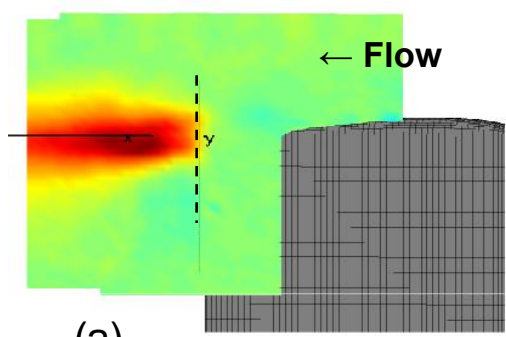

(a)

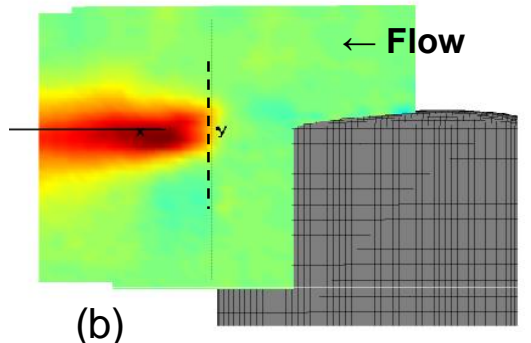

(b)

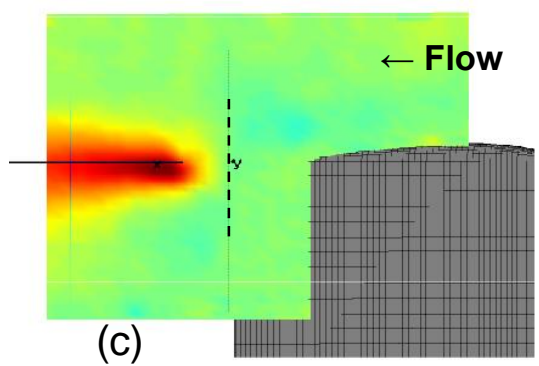

(c)

Fig. 18 Starting position of the vortex generation (experiment): (a) off; (b) suction; (c) blowing. 


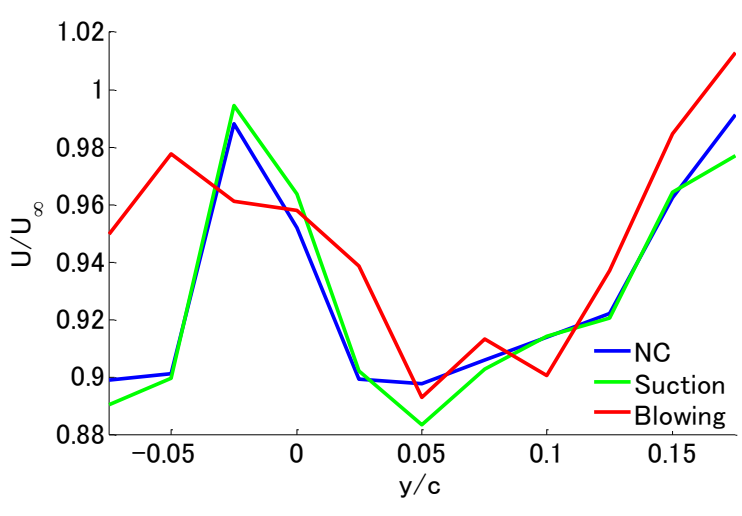

Fig. 19 Streamwise velocity profile $x / c=0.5$ (experiment).

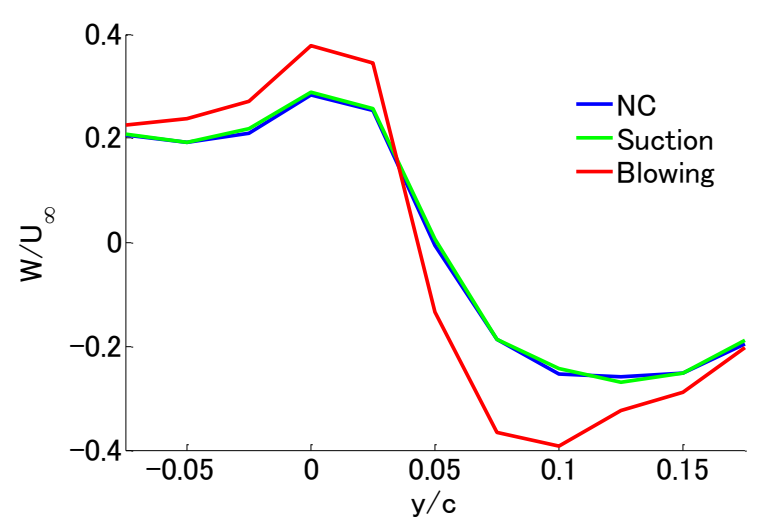

Fig. 20 Spanwise velocity profile $x / c=0.5$ (experiment).

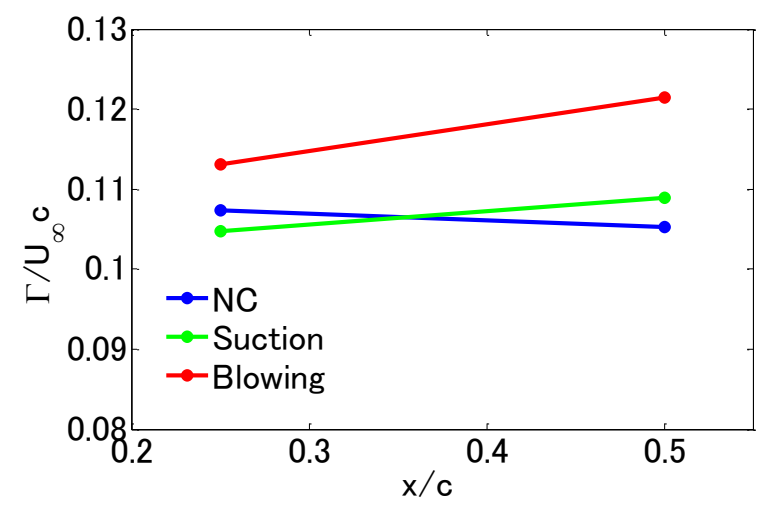

Fig. 21 Circulation parameter (experiment).

図 20 にスパン方向平均速度 $W$ の $y$ 方向分布を示寸. 数值シミュレーション（図 9(b)）と同様, NC と Suction のケース間には大きな違い見られない. Blowing のケースではスパン方向速度成分絶対值の最大值が増加すると いう数值シミュレーションと矛盾する結果が得られたが，これは誘起速度の不足により理想的に巻き上がりと対 向する流れが作り出せなかったためだと考えられる.

図 21 は循環パラメータ $\Gamma /\left(U_{\infty} c\right)$ による比較結果である.ここで循環はスパン方向最大速度の絶対值 $|W|_{\max }$ と 渦半径 $R$ を用いて循環を $\Gamma=2 \pi R|W|_{\max }$ と評価した. 数值シミュレーションと比べると概してアクチュエーション の効果は小さいが, Blowing のケースにおいては $x / c=0.25$ から $x / c=0.5$ にかけて循環パラメータが増加し, 数值 シミュレーション結果と定性的に同様の傾向となった. Suction のケースにおいては殆ど変化が見られなかったが, これは実験で用いたアクチュエーションの強度が不足していたためだと考えられる.

\section{5. 結}

プラズマアクチュエータを用いた翼端渦の抑制を目指して，プラズマアクチュエータによる誘起流れが翼端渦 に及ぼす影響について直接数值シミュレーションを用いて調査した。吹出し，吸込みの両ケースにおいて揚抗比 の低下が見られたが，循環パラメータの変化からは吹出し，吸込みのケースともに翼端渦が抑制されることが分 かった. また, 流れ場の変化からは, 吹出し, 吸込みにおける翼端渦の抑制機構は異なっているとことが伺えた. 即ち, Blowing では巻き上がりと対向する方向に流れを誘起することにより渦度そのものを減少させるのに対し， Suction では巻き上がりを支援することにより，渦直径を減少させており，これらがそれぞれのケースにおける循 環の減少の原因となっていると考えられる. 
また，同様の系を用いた風洞実験を行った，実験装置の制約上，用いたアクチュエーション強度が不十分であ ったのと, 数值シミュレーションにおいて循環パラメータの顕著な減少が見られた下流領域 $(x / c=1)$ での計測がで きなかったため，翼端渦の抑制効果は確認できなかったが，速度欠損や循環パラメータなど，主要な統計量の変 化においては数值シミュレーション結果と定性的に整合する傾向が得られた.

本研究ではプラズマアクチュエータを用いた翼端渦抑制の可能性についての基本的な調査を行ったが，さらに 主流流速やアクチュエータの配置や強度などを変化させた計算および実験を行い, 系統的な調查を行う必要があ る. 今後の課題としたい.

\section{謝辞}

本研究を行うにあたり, 慶應義塾大学・小尾晋之介博士および産業技術総合研究所・瀬川武彦博士には貴重な ご助言を頂いた．また，本研究における風洞実験は産業技術総合研究所の風洞を用いて行われた．記して謝意を 表する.

\section{文献}

（1）佐宗章弘，“可動部のない流体制御装置 : プラズマアクチュエータ”，日本機械学会誌, Vol. 110, No. 1061 (2007), p. 58.

（2）藤井孝藏，松野隆，“DBD プラズマアクチュエーターバリア放電を利用した新しい流体制御技術”，日本機械学 会流体工学部門ニューズレター「流れ」，2007 年 12 月号,〈http://www.jsme-fed.org〉.

(3) Corke, T. C., Enloe, C. L., and Wilkinson, S. P., "Dielectric barrier discharge plasma actuators for flow control," Annual Review of Fluid Mechanics, Vol. 42 (2010), pp. 505-529.

（4）深潟康二，山田俊輔，石川仁，“プラズマアクチュエータの基礎と研究動向”，ながれ，Vol. 24, No. 4 (2010), pp. 243-250.

(5) Roth, J. R. and Dai, X., "Optimization of the aerodynamic plasma actuator as an electrohydrodynamic (EHD) electric device," AIAA Paper (2006), Paper 2006-1203.

(6) Orlov, B. M., "Modeling and simulation of single dielectric barrier discharge plasma actuators," Dissertation, University of Notre Dame (2006).

(7) Post, M. L., "Plasma actuators for separation control on stationary and unstationary airfoils," Dissertation, University of Notre Dame (2004).

(8) Enloe, C. L., McLaughlin, T. E., VanDyken, R. D., Kachner, K. D., Jumper, E. J., Corke, T. C., Post, M., and Haddad O., "Mechanism and responses of a single-dielectric barrier plasma actuator: geometric effects," AIAA Journal, Vol. 42 (2004) pp. 595-604.

(9) Jukes, T. N., Choi, K.-S., Johnson, G. A., and Scott, S. J., "Turbulent drag reduction by surface plasma through spanwise flow oscillation," AIAA Paper (2006), Paper 2006-3230.

(10) Samimy, M., Kastner, J., Kim, J.-H., Utkin, Y., Adamovich, I., and Brown, C. A., "Flow and noise control in high speed and high Reynolds number jets using plasma actuators," AIAA Paper (2006), Paper 2006-2846.

(11) Roth, J. R., Sherman, D. M., and Wilkinson, S. P., "Boundary layer flow control with a one atmosphere uniform glow discharge," AIAA Paper (1998), Paper 98-0328.

(12) Corke, T. C., Jumper, E. J., Post, M. L., Orlov, D., and McLaughlin, T. E., "Application of weakly-ionized plasmas as wing flow-control devices," AIAA Paper (2002), Paper 2002-0350.

(13) 藤井孝藏, 浅田健吾, “DBD プラズマアクチュエータによる翼剥離制御メカニズムーバース卜波解析が語るもの 一”，ながれ, Vol. 24, No. 4 (2010), 259-270.

(14) Chow, J., Zilliac, G., and Bradshaw, P., "Turbulence measurements in the near field of a wingtip vortex," NASA Technical Memorandum, No. 110418 (1997), 261 pp.

(15) Devenport, W. J., Rife, M. C., Stergiios, I. L., and Follin, G. J., "The structure and development of a wing-tip vortex," 
Journal of Fluid Mechanics, Vol. 312 (1996), pp. 67-106.

(16) Bailey, S. C. C. and Tavoularis, S., "Measurements of the velocity field of a wing-tip vortex, wandering in grid turbulence," Journal of Fluid Mechanics, Vol. 601 (2008), pp. 281-315.

(17) Naka, Y., Azegami, S., Kawata, T., Fukagata, K., and Obi, S., "Simultaneous measurement of velocity and pressure in a wing-tip vortex," Journal of Fluid Science and Technology, Vol. 4 (2009), pp. 107-115.

(18) ANA NEWS，“本邦初 ボーイング 767-300ER にウイングレット！〜エコロジープラン 2008-2011の実現に向けて 〜 , <http://www.ana.co.jp/pr/08-0709/08-089.html>.

(19) Tavella, D. A. and Roberts, L., "The concept of lateral blowing," AIAA Paper (1985), Paper 85-5000.

(20) Lee, C. S., Tavella, D., Wood, N. J., and Roberts, L., "Flow structure and scaling laws in lateral wing-tip blowing," AIAA Journal, Vol. 27 (1989), pp. 1002-1007.

(21) Duraisamy, K. and Baeder, J. D., “Control of tip vortex structure using steady and oscillatory blowing,” AIAA Paper (2003), Paper 2003-3407.

(22) Okada, S. and Hiraoka, K., "Experimental studies of reduction of the wing tip vortex by suction," AIAA Paper (2003), Paper 2003-3533.

(23) 大河内翔平，笠木伸英，鈴木雄二，“マイクロ・プラズマアクチュエータの特性” ，ながれ，Vol. 24, No. 4 (2010), pp. 271-276.

(24) Fukagata, K., Kasagi, N., and Koumoutsakos, P., "A theoretical prediction of friction drag reduction in turbulent flow by superhydrophobic surfaces," Physics of Fluids, Vol. 18 (2006), Art. No. 051703.

(25) 梶島岳夫，“不等間隔格子に適合寸る対流項の差分法”，日本機械学会論文集 B 編, Vol. 65, No. 633 (1999), pp. 1607-1613.

(26) Spalart, P. R., Moser, R. D., and Rogers, M. M., "Spectral methods for the Navier-Stokes equations with one infinite and two periodic directions," Journal of Computational Physics, Vol. 96 (1991), pp. 297-324.

(27) Ducowicz, J. K. and Dvinsky, A. S., “Approximate factorization as a high order splitting for the implicit incompressible flow equations," Journal of Computational Physics, Vol. 102 (1992), pp. 336-347.

(28) Mitsuishi, A., Fukagata, K., and Kasagi, N., "Near-field development of large-scale vortical structures in a controlled confined coaxial jet," Journal of Turbulence, Vol. 8, N23 (2007), pp. 1-27.

(29) Kim, J., Kim, D., and Choi, H., "An immersed-boundary finite-volume method for simulations of flow in complex geometries,” Journal of Computational Physics, Vol. 171 (2001), pp. 132-150.

(30) Taira, K. and Colonius, T., "Three-dimensional separated flows around low-aspect-ratio flat plates," Journal of Fluid Mechanics, Vol. 623 (2009), pp. 187-207.

(31) Shyy, W., Jayaraman, B., and Anderson, A., "Modeling of glow discharge-induced fluid dynamics," Journal of Applied Physics, Vol. 92 (2002), pp. 6434-6443.

(32) Forte, M., Jolibois, J., Pons, J., Moreau, E., Touchard, G., and Cazalens, M., "Optimization of a dielectric barrier discharge actuator by stationary and non-stationary measurements of the induced flow velocity: application to airfoil control," Experiments in Fluids, Vol. 43 (2007), pp. 917-928. 